\title{
HOW IMPORTANT ARE INTERGENERATIONAL TRANSFERS FOR BABY BOOMERS?
}

Alicia H. Munnell, Anthony Webb, Zhenya Karamcheva, and Andrew Eschtruth

CRR WP 2011-1

Date Released: January 2011

Date Submitted: January 2011

\author{
Center for Retirement Research at Boston College \\ Hovey House \\ 140 Commonwealth Avenue \\ Chestnut Hill, MA 02467 \\ Tel: 617-552-1762 Fax: 617-552-0191 \\ http://crr.bc.edu
}

\begin{abstract}
All of the authors are with the Center for Retirement Research at Boston College (CRR). Alicia H. Munnell is director of the CRR and the Peter F. Drucker Professor of Management Sciences at Boston College's Carroll School of Management. Anthony Webb is a research economist. Zhenya Karamcheva is a research associate. Andrew Eschtruth is associate director for external relations. The CRR gratefully acknowledges the MetLife Mature Market Institute for its generous support of this research. The findings and conclusions expressed are solely those of the authors and do not represent the views of the MetLife Mature Market Institute or the CRR.

(C) 2011, by Alicia H. Munnell, Anthony Webb, Zhenya Karamcheva, and Andrew Eschtruth. All rights reserved. Short sections of text, not to exceed two paragraphs, may be quoted without explicit permission provided that full credit, including ( $\subseteq$ notice, is given to the source.
\end{abstract}




\title{
About the Center for Retirement Research
}

The Center for Retirement Research at Boston College, part of a consortium that includes parallel centers at the University of Michigan and the National Bureau of Economic Research, was established in 1998 through a grant from the Social Security Administration. The Center's mission is to produce first-class research and forge a strong link between the academic community and decision makers in the public and private sectors around an issue of critical importance to the nation's future. To achieve this mission, the Center sponsors a wide variety of research projects, transmits new findings to a broad audience, trains new scholars, and broadens access to valuable data sources.

\author{
Center for Retirement Research at Boston College \\ Hovey House \\ 140 Commonwealth Avenue \\ Chestnut Hill, MA 02467 \\ phone: 617-552-1762 fax: 617-552-0191 \\ e-mail: crr@bc.edu \\ crr.bc.edu
}

\section{Affiliated Institutions:}

The Brookings Institution Massachusetts Institute of Technology

Syracuse University

Urban Institute 


\begin{abstract}
Due to a changing retirement landscape, many baby boomers are likely to have insufficient resources for a secure retirement. One potential source that could improve their situation is inheritances. Using data from the Survey of Consumer Finances and the Health and Retirement Study, this study quantifies how much boomers can expect to inherit. Our best estimate is that boomers’ will inherit \$8.4 trillion. Of this amount, \$2.4 trillion has already been received, while the remaining $\$ 6.0$ trillion is anticipated. We estimate that two-thirds of boomer households will receive some inheritance over their lifetime, with a median amount of $\$ 64,000$. The estimates are based on data obtained before the economic crisis, so our analysis explores how the collapse in the stock and housing markets might affect the picture. Evidence from the previous economic crisis in the early 2000s suggests only a temporary reduction in prospective inheritances, which will be reversed as the economy recovers. However, given the severity of the recent crisis, we also considered a scenario in which inheritances fall proportionately with the decline in housing and stock values between 2007 and 2010. In this case, anticipated inheritances would fall 13 percent - from 6.0 trillion to \$5.2 trillion. In any case, any prospective inheritance is uncertain. Parents or grandparents who expect to leave a bequest may revise their plans based on fluctuations in their asset values. Or they may exhaust their wealth due to medical costs or long lifespans. In short, boomers should not count on an anticipated inheritance to eliminate the need for increased retirement saving.
\end{abstract}




\section{Introduction}

Due to a changing retirement landscape, many baby boomers are likely to have insufficient resources for a secure retirement. ${ }^{1}$ One potential source that could improve their situation is intergenerational transfers, such as inheritances. Although the extent to which such transfers contribute to household wealth has been the subject of vigorous debate, it is clear that they are important in aggregate, and economically significant for some households. ${ }^{2}$

This study quantifies the aggregate amount that baby boomers - those individuals born between 1946 and 1964 - can expect to receive over their lifetimes, and the distribution of past and prospective receipts by household type.

The discussion is organized as follows. The first section quantifies the aggregate amount that boomers will receive over their lifetimes and reconciles our findings to those of previous research. The second section compares boomers' receipts with those of previous birth cohorts. The third section considers the potential impact of inter-vivos transfers. The fourth section investigates who will receive how much, when, and from whom. The fifth section considers how much boomers might in turn transfer to their children and parents. The sixth section considers the impact of the recession on intergenerational transfers, specifically the declining values of equities and housing. The final section concludes that, while intergenerational transfers will augment the resources of aging baby boomers, they will be insufficient to ensure secure retirements. The study contains an appendix describing the data and explaining the methodology.

\section{How Much Will Boomers Receive in Aggregate?}

To assess how much boomers will inherit, we use data from the Survey of Consumer Finances (SCF) and the Health and Retirement Study (HRS). The SCF is a triennial

\footnotetext{
${ }^{1}$ These changes include declining Social Security replacement rates, the shift to 401(k) plans accompanied by low saving rates, longer lifespans, and rising health care costs. For more details, see Vanderhei and Copeland (2010); and Munnell, Webb, and Golub-Sass (2009).

${ }^{2}$ Kotlikoff and Summers (1981) estimated that 46 to 80 percent of household wealth is due to inheritances. In contrast, Modigliani (1988) estimated that only 20 percent was the result of intergenerational transfers. Kotlikoff (1988) finds that the difference between the two calculations is largely the result of differences in the treatment of earnings on inherited wealth.
} 
survey that oversamples wealthy households; the latest available data are for 2007. When re-weighted, it is representative of the U.S. population. SCF participants are asked about past receipts of inheritances and of inter-vivos gifts (those made during the donor's lifetime). They are also asked whether they expect a substantial inheritance or transfer of assets in the future, and the anticipated amount. But "expect" and "substantial" are left undefined, and only 16 percent of households answer in the affirmative. For data on prospective inheritance receipts, we therefore turn to the HRS, a nationally representative panel of individuals born before 1954 and their spouses of any age. In 2006, individuals were asked to estimate the probability of receiving an inheritance in the next 10 years, and the likely amount. We convert these 10-year forecasts into lifetime probabilities, and impute probabilities and amounts to SCF households born between 1946 and 1964, to obtain a complete picture of past and prospective inheritance receipts for the baby boomers. ${ }^{3}$ Unfortunately, they were not asked about prospective inter-vivos transfers.

Inheritances can be received at various ages, and a dollar received at a younger age is worth more in present value terms than a dollar received later in life. Therefore, the key question is what interest rate to use for compounding or discounting the amounts. One approach, taken by Havens and Schervish (1999), is not to apply any time discounting at all. This method places an equal value on an inflation-adjusted dollar, regardless of the date of receipt. At the other extreme, one could discount receipts at the rate of return on financial assets. This approach produces very large present values for inheritances received in the distant past and very small present values for those the household anticipates receiving in the distant future. We follow Brown and Weisbenner (2004) and use a real discount rate of 3 percent in our base case, approximating to both the long-term rate of return on high-grade corporate bonds and commonly used estimates of the rate of time preference. But to facilitate comparison with Havens and Schervish (1999), we also report calculations using a zero percent discount rate. As our objective is to value past and

\footnotetext{
${ }^{3}$ A potential concern is that households may under-report receipts (Kessler and Masson, 1989; and Gale and Scholz, 1994). However, Brown and Weisbenner (2004) show that aggregate numbers obtained from selfreported inheritance data are consistent with those obtained from models of transfer flows. And Coe and Webb (2009) compare households' estimates of prospective inheritance receipts with subsequent outcomes and find no evidence of systematic biases.
} 
prospective inheritance receipts as of a current date, we discount and compound all amounts to 2009. ${ }^{4}$

Table 1 reports estimates of aggregate and per household receipts. At a 3-percent interest rate, total, past, and prospective receipts amount to $\$ 8.4, \$ 2.4$, and $\$ 6.0$ trillion respectively. At a zero-percent interest rate, less weight is attached to past and more weight to prospective receipts. Total, past, and prospective receipts then amount to $\$ 9.2$, \$1.5, and \$7.7 trillion, respectively. The comparable data per household show similar patterns; at a 3-percent interest rate, the median total inheritance is $\$ 64,000$ and the mean is $\$ 292,000$. Strikingly, the mean is more than four times the median, as those near the top of the distribution receive much larger inheritances in dollar terms.

The choice of discount rate has little effect on the 2009 present value of the sum of past and prospective inheritance receipts. At a higher discount rate, the increase in the present value of past inheritance receipts is offset by the reduction in the present value of prospective receipts. To put the $\$ 8.4$ trillion in context, our analysis of SCF data shows that, in 2007, total household wealth for all ages amounted to \$65.9 trillion in 2009 dollars. ${ }^{5}$

The aggregate numbers above are consistent with the findings of previous research, after adjusting for inflation. Using a zero percent discount rate, Havens and Schervish (1999) estimated that during the period 1998-2052, bequests to heirs of all ages might amount to upward of $\$ 24$ trillion 1998 dollars and could conceivably be as high as $\$ 65$ trillion. Havens and Schervish (2003) estimated that boomers may well receive $\$ 7.2$ trillion of the \$24 trillion. The \$7.2 trillion equates to \$9.5 trillion in 2009 dollars. Eliminating inheritances received prior to 1998 reduces our zero-percent discount rate estimate of $\$ 9.2$

\footnotetext{
${ }^{4}$ An alternative would be to discount inheritances to a common age, which would decrease the value of the inheritances of older relative to those of younger households.

${ }^{5}$ Household wealth is defined as the sum of financial assets, housing wealth, business assets and other nonfinancial wealth exclusive of defined benefit pensions and Social Security assets, net of any debt or other liabilities.
} 
trillion to $\$ 8.4$ trillion. Our estimate is thus of the same order of magnitude as that of Havens and Schervish (2003). ${ }^{6}$

\section{How Do Boomers' Receipts Compare With Those of Previous Birth Cohorts?}

To answer this question, we compare the amounts the boomers had received by 2007, when they were 43 to 61 years old, with the amounts that households born between 1927 and 1945 had received by 1989, when they were also 43 to 61 years old. The 1989 amounts are restated in 2009 dollars, and amounts received in years prior to 1989 are compounded using a 3-percent real interest rate. No comparable 1989 data are available for prospective inheritance receipts.

By 1989, the 1927-1945 birth cohort had received \$1.5 trillion, compared with the $\$ 2.4$ trillion received by the 1946-1964 birth cohort by 2007 (see Table 2). But the boomer birth cohort was nearly 70 percent larger than the 1927-45 birth cohort, and the median present value amount received per household was only slightly larger in 2009 dollars. ${ }^{7}$ This result is at first glance surprising, given the dramatic increase in household wealth during the post-war period. Part of the explanation is reductions in mortality. The majority of transfers from parents to children occur on the death of the surviving spouse. For households born 1927-45, 23 percent had received an inheritance by 1989; the comparable figure for those born 1946-64 was 17 percent in 2007. This gap reflects different mortality patterns of their parents’ generation; 25 percent of households born 1927-45 had no surviving parent in 1989 - and thus were candidates for having received substantial inheritances - whereas 21 percent of those born 1946-64 had no surviving parent in 2007. Reduced mortality may also reduce the amount that individuals plan to bequeath as they require a larger pile of assets to cover their own needs over a lengthier

\footnotetext{
${ }^{6}$ Avery and Rendall (1993) estimate total inheritance flows over the period 1990-2040 at \$10 trillion in 1990 dollars. They do not indicate what portion will be received by the baby boomers. Their number can therefore only be compared with the Havens and Schervish (1999) \$24 trillion total for all birth cohorts, which is 140 percent larger. Our analyses of SCF data show that the total wealth of households aged 65 and over increased by 60 percent between 1989 and 1998. The Avery and Rendell estimate therefore appears somewhat low, relative to those of Havens and Schervish (1999) and to our own estimate.

${ }^{7}$ In 2007, the boomer cohort comprised 43.7 million households. In 1989, the 1927-45 birth cohort comprised 26.0 million households.
} 
retirement period. An additional explanation is that bequests passing to the 1946-64 birth cohort had to be shared among a larger number of siblings.

\section{How Much Does the Inclusion of Inter-vivos Gifts Affect the Numbers?}

Estimates of inter-vivos transfers can be constructed from the responses of either recipients or transferors. Using data from the 1986 SCF, Gale and Scholz (1994) compared responses of recipients and transferors. They found that the use of data collected from recipients yielded estimates of the participation rate and aggregate amount transferred that were substantially lower than those based upon data collected from transferors. This pattern suggests a greater willingness on the part of respondents to report transfers they have made rather than transfers they have received. The reasons are likely related to psychology; givers tend to account for their gifts more carefully because it improves their self image, while recipients tend to underestimate the gifts they have received because they do not want to think of themselves as financially dependent. As a result, estimates constructed from transferor data might be more reliable.

However, while transferor data may be reported more accurately, they suffer from a different limitation - it is hard to determine the recipients of the transfers. This limitation makes it difficult to construct a nationally representative sample of recipients. Our analysis required a sample that is representative of the whole boomer generation. Therefore, we used recipient data for our estimates.

Neither recipients nor transferors are asked specifically about college tuition payments. It seems likely that this type of transfer will be substantially under-reported by both recipients and transferors.

When inter-vivos transfers are included, transfers received to date increase by 38 percent, from \$2.4 trillion to \$3.4 trillion. If inter-vivos transfers represent the same proportion of prospective inheritances, then the lifetime total increases from \$8.4 to \$11.6 trillion. 


\section{Who Receives How Much, When, and From Whom?}

Past inheritance receipts are very unequally distributed, with just 17 percent of households having received anything. But, in 2007, 58 percent of boomer households had at least one living parent, ${ }^{8}$ so analyses of amounts received to date therefore substantially understate the proportion of households that will eventually receive an inheritance. Taking into account both past and future inheritances, we estimate that two-thirds of boomer households will receive some inheritance. This figure may sound surprisingly high. To verify our results, we compared data from both the SCF and HRS on past inheritances for early boomers. The results from the two datasets are comparable with about 20 percent of households having already received an inheritance by 2007 (SCF) or 2006 (HRS). To calculate future inheritances, we relied exclusively on the HRS given its more precise data in this area. In both 2004 and 2006, about 50 percent of early boomers report a positive probability of receiving an inheritance in the next 10 years. Combining the past and future figures suggests that our estimate that two-thirds of households will eventually receive an inheritance is reasonable.

Figure 1 shows the distribution of lifetime inheritance receipts. About one-third of boomer households expect to receive no inheritance over their lifetime. About threequarters expect either no inheritance or less than $\$ 100,000$, and 97 percent expect either no inheritance or less than $\$ 1$ million. ${ }^{9}$

Figure 2 analyzes the percentage of boomer households that have either received or anticipate receiving an inheritance, by income decile. Although the incidence of receipt increases with income, 50 percent or more of households in all income deciles will eventually receive an inheritance.

\footnotetext{
${ }^{8}$ For a married household, we define "having a living parent” as both spouses having at least one living parent.

${ }_{9}^{9}$ All the calculations in this section compound past inheritances and discount anticipated inheritances at a 3percent real interest rate.
} 
Figure 3 shows mean lifetime receipt, conditional on receiving an inheritance, by wealth decile. ${ }^{10}$ High-wealth households receive substantially larger inheritances - an average of $\$ 1.5$ million for those in the top wealth decile, compared with $\$ 27,000$ for those in the bottom wealth decile. Even within wealth deciles, inheritances are very unequally distributed; the medians for the top and bottom deciles are $\$ 335,000$ and $\$ 8,000$ respectively.

Figure 3 also shows the mean amount received as a percent of mean household wealth for the relevant wealth decile. On average, inheritance receipts represent a smaller percentage of current wealth for high-wealth households - 22 percent for those households in the top wealth decile, compared with 64 percent for those households in the second-to-bottom wealth decile. ${ }^{11}$

Figure 4 shows the average lifetime receipt, by wealth decile. In contrast to Figure 3, which shows the average amount, conditional on receiving anything, this figure shows unconditional means. Households in the top wealth decile receive dramatically more than those in the bottom decile - an average of $\$ 1.1$ million, compared with $\$ 9,000$. But inheritances represent a smaller percentage of the current wealth of high-wealth households - 20 percent for those in the top wealth decile, compared with 50 percent for those in the second-to-bottom wealth decile.

Figure 5 shows the percent of boomers receiving an inheritance by five-year age group. ${ }^{12}$ Less than 1 percent of boomers received an inheritance between age 20 and 24. But the probability of receipt increases with age, reflecting a pattern in which most inheritances are received from parents, passing on the death of the surviving parent, with boomers now approaching the ages at which many such deaths are occurring. So 13.7 percent of those

\footnotetext{
${ }^{10}$ For our definition of wealth, see footnote 5. In addition, when calculating household wealth deciles, we include the present value of anticipated inheritance receipts.

${ }^{11}$ Our emphasis is on the second-to-bottom wealth decile rather than the bottom decile because households in the bottom decile have so little wealth, even after including inheritances, that inheritances as a percent of wealth is not a meaningful number.

12 Our calculations are adjusted to reflect the fact that not all boomers are observed to age 61 .
} 
boomers who had attained age 59 by 2007 received an inheritance between ages 55 and 59.

Table 3 analyzes past inheritance receipts by source. To date, the overwhelming majority of the boomers' inheritances have been received from parents, with grandparents and aunts and uncles being the second and third most common sources. Few boomers now have living grandparents, but the majority has at least one living parent. So parents are likely to be the predominant source of inheritances in coming years.

\section{How Much Might Boomers Leave to Succeeding Generations?}

The boomer generation is currently 46 to 64 years old. Munnell, Webb, and Golub-Sass (2009) document the inadequate financial preparedness for retirement of this birth cohort. This cohort also faces rising health care costs, the largely uninsured cost of long-term care, the risk of job loss, and declines in prospective returns on their accumulated wealth. Some have yet to face the potentially substantial cost of paying for their children's college education and may also be called upon to contribute to the cost of their grandchildren's education. The above factors could lead one to conclude that the boomers might be less likely than previous birth cohorts to leave bequests to succeeding generations.

Offsetting the above factors are the effects of the change in the composition of pension wealth. Defined contribution pension plans, which are rarely annuitized, have rapidly displaced defined benefit pension plans in the private sector, while lump-sum options have become more prevalent in the remaining defined benefit pension plans. Households managing the decumulation of unannuitized wealth will almost invariably die leaving part of that wealth unconsumed, even if they lack an operative bequest motive. Munnell et al. (2003) estimate that the increase in pension lump-sum payments over the period 19922004 resulted in substantial increases in bequests. They also found evidence that the growth in lump-sum payments might be raising the interest of households in leaving an intended bequest. 
Estimating how these offsetting factors will affect boomer bequest behavior is difficult given the 20- to 50-year remaining life expectancy of the boomer cohort. In addition, considering that a large number of boomers have not yet received inheritances themselves, we conclude that their current bequest intentions may provide little information about their future bequest decisions.

\section{How Has the Recession Affected Prospective Inheritances?}

This section considers how the financial crisis might affect boomers' prospective inheritance receipts. The crisis has resulted in steep declines in both housing and stock prices. These declines might affect prospective inheritances in a number of ways. At one extreme, boomers' parents might strive to maintain pre-crisis consumption, letting the entire burden of the reduction in asset values fall on bequests. At the other extreme, they might choose to reduce their current consumption while attempting to leave the same amount of wealth to their heirs as previously. Or they might decide to make proportionate cutbacks in both current consumption and bequests. ${ }^{13}$

To determine the effects of the crisis, we would, ideally, use survey data collected after the crisis began. The 2008 HRS does not meet our needs for two reasons. First, most of the households were interviewed before the collapse of Lehman Brothers in September 2008, which ushered in the most serious phase of the financial crisis. Second, the 2008 HRS has more limited data on inheritances than previous years of the survey. ${ }^{14}$ The SCF is also not an option as the latest full version of the survey was conducted in 2007, before the crisis, and a special version conducted in 2009 is not yet available.

Due to these data limitations, we adopt two complementary approaches to quantifying the impact of the current recession on prospective inheritances. The first examines the

\footnotetext{
${ }^{13}$ This last outcome may not necessarily arise as a result of a desire to leave a bequest. A household that has a constant relative risk aversion utility function and is lacking a bequest motive would adjust its consumption proportionately with the reduction in wealth, and would leave a proportionately smaller bequest.

14 In 2009, a subsample of HRS participants completed an Internet questionnaire that included questions about bequest intentions. These respondents have higher than average socio-economic status. Therefore, we decided it would be misleading to use these data to draw inferences about the impact of the financial crisis on bequest intentions.
} 
reactions of households to the previous economic downturn in the early 2000s. The second directly assesses the current downturn by assuming that inheritances will fall proportionately with the decline in asset values experienced since 2008.

\section{Approach 1: How Bequests Changed in the Previous Downturn}

HRS data allow us to draw inferences from households' responses to past financial crises, in particular the decline in stock prices from 2000 to 2003. HRS participants are asked a series of questions that provide data on the probability of a household leaving a bequest and the amount of the potential bequest. ${ }^{15}$

Using these HRS data in pooled cross section, we estimate an ordered probit model to identify the impact of stock market conditions on household responses over time. The analysis controls for a variety of socioeconomic characteristics, includes a full set of year dummies, and is restricted to those aged 65 or over at the date of the interview. We hypothesize that households will be less likely to report that they anticipate leaving a large inheritance in 2002, when they had experienced a substantial decline in the stock market. We further hypothesize that the greatest effect will be among households with substantial exposure to the stock market. We therefore interact the year dummies with a variable taking the value one if the household had $\$ 25,000$ or more invested in the stock market, zero otherwise.

Table 4 reports the impact of the year dummies and year dummies interacted with stock ownership on the predicted percent of households falling into each of the five response categories, holding personal characteristics constant at their means. So in 2000, the entries in the first row show that a predicted 2.1 percent of households who had more than $\$ 25,000$ invested in the stock market would report that they had a zero percent chance of leaving any inheritance. Just 22.5 percent definitely plan to leave an inheritance of $\$ 100,000$ or more.

\footnotetext{
${ }^{15}$ Since 1994, HRS participants have been asked to assess the probability of leaving an inheritance that exceeds threshold amounts of $\$ 10,000$ and $\$ 100,000$. In 2004 and subsequent years, those estimating some probability of leaving $\$ 100,000$ or more have been asked to assess the probability of leaving $\$ 500,000$ or more.
} 
Although the changes in probabilities are sometimes statistically significant, they are generally small. For example, the decline in stock prices between 2000 and 2004 was associated with only a 3.8 percentage-point (22.5 - 18.7) decline in the number of households who were certain of leaving an inheritance of $\$ 100,000$ or more. Not only is this decline small but, by 2006, it began to reverse.

Although households with substantial stock portfolios were more likely to anticipate leaving a substantial inheritance, there was no statistically significant difference between their response to the downturn in the stock market between 2000 and 2004 and that of households with little or no exposure to the stock market.

One possible explanation for the small magnitude of the above responses is that older households plan to reduce consumption in order to preserve the value of their intended bequest. But we cannot rule out the possibility that households take time to adjust their expectations in the light of realized investment returns.

\section{Approach 2: How Much Bequests Could Change Due to the Current Downturn}

The previous analysis found only small reductions in anticipated bequests in the previous downturn, suggesting that older households are willing to sacrifice consumption to maintain their intended bequests. If so, this result represents one possible extreme. The other extreme is that older households are not willing to sacrifice their consumption and, instead, reduce intended bequests by the full amount of the decline in assets that they experience, an outcome that we deem unlikely. Therefore, our second approach assumes cutbacks in both consumption and intended bequests.

We assume that anticipated inheritance receipts decrease proportionately with the declines in stock and house prices from the date of the 2006 HRS interview to May 2010. ${ }^{16}$ Since respondents are not asked about their parents' portfolio allocations, we assume that all persons who might leave bequests to the boomers have the average portfolio allocation for

\footnotetext{
${ }^{16}$ We use the S\&P 500 and the S\&P/Case-Shiller house price index.
} 
households aged 65 and over, calculated from SCF data. ${ }^{17}$ Table 5 shows the composition of total wealth of this age group as of 2007. Housing comprises 33.1 percent of the total. We assume that 50 percent of defined contribution and 80 percent of mutual fund balances are held in stocks, so stocks represent 19.6 percent of total household wealth. The average date of the HRS interviews was June 2006. Between June 2006 and June 2010, house prices, as measured by the S\&P/Case-Shiller index, declined by 28.3 percent. ${ }^{18}$ The S\&P 500 index declined by 18.9 percent over the same period. ${ }^{19}$ Multiplying by the percentages of household wealth invested in stocks and housing yields a decline in wealth of 13.1 percent. Applying this percentage reduction to our earlier estimate of prospective inheritances reduces the estimate from $\$ 6.0$ to $\$ 5.2$ trillion. $^{20}$ Thus, the declines in asset prices will reduce inheritance receipts, but substantial amounts will still pass to succeeding generations.

\section{Conclusion}

Boomers are likely to receive inheritances totaling upward of $\$ 8$ trillion over their lifetimes. Among the two-thirds of boomer households expected to receive an inheritance, the median amount is $\$ 64,000$. Inheritances are very unequally distributed, and many households will receive small amounts. But a substantial minority can expect to receive amounts that will improve their financial preparedness for retirement, and their ability to pass wealth to succeeding generations.

These findings have useful implications for boomers, their financial advisors, and policymakers concerned about retirement security. First, it is important to stress that most boomers have not yet received any inheritance. And the amount and timing of inheritance receipts is highly uncertain. Even parents who have a strong desire to leave a bequest may be forced to revise their plans based on fluctuations in the value of their assets. Or they

\footnotetext{
${ }^{17}$ Stock and house prices have declined by similar proportions. So it is unclear whether the financial crisis has had a greater effect on the wealthy, who hold a larger proportion of their wealth in stocks, or on the majority of the population, who hold most of their non-pension wealth in housing.

18 The June 2006 and June 2010 index values were 206.38 and 147.97, respectively. http://www.standardandpoors.com/indices/main/en/us

19 The S\&P 500 closed at 1270.2 on 30 June 2006 and 1030.71 on 30 June 2010.

${ }^{20}$ Business assets comprise 18.3 percent of the wealth of households over 65 , and it is likely that the recession also had a substantial impact on the market value and profit earning potential of these assets.
} 
may exhaust their wealth as a result of medical and especially long-term care costs. In short, an anticipated inheritance may not materialize. Even when inheritances do occur, recipients generally get the money when they are older and the amounts are typically not large enough to be life-changing. Therefore, boomer households need to make many of their key financial decisions before they ever receive any inheritance. And they should not count on an inheritance to eliminate the need for increased retirement saving. ${ }^{21}$

Second, to improve boomers' ability to gauge how inheritances might help them, the subject could be used to generate intra-family discussions about estate planning. While not everyone will be comfortable engaging in this subject, those who are able to do so will likely find the opportunity helpful. A trusted family financial advisor may be useful in this regard as an outside individual who can help bring both parents and children together to handle the topic.

Finally, policymakers should recognize that inheritances are not a silver bullet to achieve retirement security for an aging population. So they should continue to develop initiatives to boost Americans’ saving and promote longer worklives. One policy that will not have a major effect on boomers' retirement preparedness is the estate tax. Regardless of whether the estate tax rules change when the current provisions expire, it will affect only a very small minority of households.

\footnotetext{
${ }^{21}$ Brown and Weisbenner (2004) find that although past inheritance receipts "crowd out" saving by the recipient household dollar for dollar, the same is not true of anticipated receipts.
} 


\section{References}

Avery, Robert B., and Michael S. Rendall. 1993. "Estimating the Size and Distribution of Baby Boomers’ Prospective Inheritances.” 1993 Proceedings of the Social Statistics Section. Alexandria, VA: American Statistical Association: 11-19.

Brown, Jeffrey R., and Scott J. Weisbenner. 2004. "Intergenerational Transfers and Savings Behavior.” In Perspectives on the Economics of Aging, edited by David A. Wise, 181-201. Chicago: University of Chicago Press.

Coe, Norma B., and Anthony Webb. 2009. “Actual and Anticipated Inheritance Receipts.” Working Paper 2009-32. Chestnut Hill, MA: Center for Retirement Research at Boston College.

Gale, William G., and John Karl Scholz. 1994. "Intergenerational Transfers and the Accumulation of Wealth.” Journal of Economic Perspectives 8(4): 145-160.

Havens, John J., and Paul G. Schervish. 1999. "Millionaires and the Millennium: New Estimates of the Forthcoming Wealth Transfer and the prospects for a Golden Age of Philanthropy.” Working Paper. Chestnut Hill, MA: Social Welfare Institute at Boston College.

Havens, John J., and Paul G. Schervish. 2003. "Why the \$41 Trillion Wealth Transfer Estimate is Still Valid: A Review of Challenges and Questions.” Journal of Gift Planning (7): 11-15, 47-50.

Kessler, Denis, and André Masson. 1989. "Bequest and Wealth Accumulation: Are Some Pieces of the Puzzle Missing?” Journal of Economic Perspectives (3): 141-52.

Kotlikoff, Laurence J., and Lawrence H. Summers. 1981. “The Role of Intergenerational Transfers in Aggregate Capital Accumulation.” Journal of Political Economy Vol. 89 pp. 706-732

Kotlikoff, Laurence J. 1988. “Intergenerational Transfers and Savings.” Journal of Economic Perspectives 2(2): 41-58.

Modigliani, Franco. 1988. “The Role of Intergenerational Transfers and Life Cycle Saving in the Accumulation of Wealth.” Journal of Economic Perspectives Spring Vol. 2 pp. 15-40.

Munnell, Alicia H., Annika Sundén, Mauricio Soto, and Catherine Taylor. 2003. "The Impact of Defined Contribution Plans on Bequests." Death and Dollars: The Role of Gifts and Bequests in America, edited by Alicia H. Munnell and Annika Sundén, 265-316. Washington, DC: Brookings Institution Press. 
Munnell, Alicia H., Anthony Webb, and Francesca Golub-Sass. 2009. "The National Retirement Risk Index: After the Crash." Issue in Brief 2009-22. Chestnut Hill, MA: Center for Retirement Research at Boston College

Standard \& Poors. S\&P 500 Index, 2006 and 2010. New York, NY.

Standard \& Poors. S\&P/Case-Shiller Home Price Index, 2006 and 2010. New York, NY.

University of Michigan. Health and Retirement Study, 2000-2006. Ann Arbor, MI.

U.S. Board of Governors of the Federal Reserve System. Survey of Consumer Finances, 2007. Washington, DC.

Vanderhei, Jack and Craig Copeland. 2010. "The EBRI Retirement Readiness Rating:TM Retirement Income Preparation and Future Prospects.” Issue Brief 344.

Washington, DC: Employee Benefit Research Institute. 


\section{Appendix}

This appendix describes the questions asked of participants in the Survey of Consumer Finances (SCF) and the Health and Retirement Study (HRS) and outlines the methodology used to produce estimates of past and prospective inheritance receipts.

The financial respondent in each household in the SCF is asked:

"Have you or your husband/wife/partner ever received an inheritance or been given substantial assets in a trust or in some other form?"

For the largest three receipts, the respondent is asked the value at the time of receipt, the date of receipt, whether it was an inheritance, inter-vivos gift, or something else, and from whom it was received. Respondents are also asked to state the total of any other receipts, but are not asked to identify dates or sources.

In 2006, but not in 2008, respondents in the HRS were asked:

Not counting anything you might give or leave to each other, what are the chances that you or your husband/wife/partner will receive an inheritance during the next 10 years?

Respondents who assess the probability at greater than zero are then asked:

About how large do you expect that inheritance to be ${ }^{22}$

Respondents who are unable to provide a precise answer are then invited to indicate whether the anticipated receipt lies within various ranges.

Assigning prospective inheritance receipts to the SCF households involves seven steps. We first estimate a probit model on HRS data. The dependent variable takes the value one if the individual assigns a positive probability to receiving an inheritance, zero otherwise.

${ }^{22}$ We assume that responses are in 2006 dollars, and are not subject to time discounting. 
Explanatory variables include own and spouse's education, ethnicity, log of income, age, number of siblings, indicators for self and spouse having no living parents, and parents' ages - conditional on being alive. We use the parameter estimates to impute a zero or non-zero probability of receiving an inheritance to boomer households in the SCF.

We then use hot-deck imputation to assign probabilities of receipt to those SCF households that have been assigned a non-zero probability of receipt in the above step. Covariates include marital status, ethnicity, whether both parents are dead, and number of siblings.

We then estimate an OLS regression on those HRS households that assess their probability of receipt at greater than zero. The dependent variable is the log of the anticipated dollar amount, and the explanatory variables are those used in the probit model.

HRS participants are only asked to forecast inheritance receipts up to a 10-year time horizon. We estimate that in 10 years' time, 36 percent of boomers will still have at least one surviving parent. So forecasts over a 10 -year horizon will substantially understate lifetime receipts. To obtain estimates of the lifetime probability of receipt, we multiply the self-reported probabilities assigned to the SCF households by the reciprocal of the probability that both husband's and wife's surviving parents will die within the next 10 years. ${ }^{23}$ In some cases, this produces a probability that exceeds 100 percent. ${ }^{24}$ In these cases, we cap the probability at 100 percent and make a corresponding adjustment in the anticipated dollar amount.

\footnotetext{
${ }^{23}$ As we lack data on the identities of persons from whom the household anticipates receiving an inheritance, we make the simplifying assumption that all inheritances will be received from the boomers' parents. We further assume that the amount received from a parent or other relative does not depend on the parent or other relative's age of death. Households tend to decumulate wealth as they age, but wealthy individuals have greater average wealth, and give birth at older ages, so the direction of any bias is unclear.

${ }^{24}$ Some respondents will, often with good reason, assess the probability of their parents dying within 10 years at greater or less than that predicted by life tables, in which case our methodology will over- or understate the lifetime probability of receipt. Others may anticipate receiving inheritances from more than one source over their lifetime.
} 
We then make random draws from the uniform [0,1] distribution, and based on the values drawn, assign either receipt or non-receipt to each household. Those assigned receipt of an inheritance are assumed to receive the predicted amount, plus a draw from a mean zero error term. $^{25}$

An important assumption underlying the above procedure is that, conditioning on the socioeconomic characteristics used in the above regressions, prior receipt of an inheritance does not affect the probability of receiving one in the future. In theory, prior receipt might be associated with either an increased or decreased probability of receiving an inheritance in the future. If prior receipt is associated with an increased probability of receiving an inheritance in the future, our calculations will understate the extent to which the receipt of substantial inheritances is concentrated among a small segment of the population. Conversely, if prior receipt is associated with a reduced probability of subsequent receipt, our calculations will overstate the concentration of inheritance receipts.

The present value of an inheritance depends on the timing of its receipt. HRS respondents are not asked when they anticipate receipt. We assume that all inheritances pass on the death of the surviving parent. The sixth stage in the calculation involves discounting anticipated receipts by joint parental life expectancy.

SCF respondents are interviewed in 2007, whereas Health and Retirement Study participants are interviewed in the latter part of the previous year. In the seventh and final step, to eliminate double counting of inheritances received between 2006 and 2007, we exclude inheritances received during this period from all calculations based upon the sum of past and prospective inheritances. ${ }^{26}$

\footnotetext{
${ }^{25}$ The error term captures variation in the amounts of anticipated inheritance receipts that is uncorrelated with the explanatory variables used in our econometric model.

${ }^{26}$ Inheritance receipts are coded in five-year intervals. We randomly assign a year of receipt to inheritances received during the period 2003-2007.
} 
Table 1. Aggregate, Mean, and Median Inheritance Receipts in 2009 Dollars

\begin{tabular}{lccc|ccc} 
& \multicolumn{3}{c}{ 0\% Discount Rate } & \multicolumn{3}{c}{ 3\% Discount Rate } \\
\cline { 2 - 7 } & $\begin{array}{c}\text { Aggregate } \\
\text { Amount } \\
\text { (trillions) }\end{array}$ & \multicolumn{2}{c}{$\begin{array}{c}\text { Amount per } \\
\text { Household } \\
\text { (for recipients) }\end{array}$} & Total Amount & \multicolumn{3}{c}{$\begin{array}{c}\text { Amount per } \\
\text { Household } \\
\text { (frillions) }\end{array}$} & Mean recipients) & Median \\
\cline { 2 - 8 } Past & 1.5 & 53,315 & 54,925 & 2.4 & 84,494 & 78,027 \\
Prospective & 7.7 & 266,178 & 61,235 & 6.0 & 207,861 & 46,926 \\
\hline Total & 9.2 & 319,493 & 57,932 & 8.4 & 292,355 & 63,875
\end{tabular}

Note: The medians report the middle inheritance for households with a non-zero inheritance receipt in the corresponding category.

Source: Authors' calculations based on U.S. Board of Governors of the Federal Reserve System, Survey of Consumer Finances (SCF), 2007; and University of Michigan, Health and Retirement Study (HRS), 2006.

Table 2. Inheritance Receipts and Demographics of Households with Heads Age 43-61, 1989 and 2007

\begin{tabular}{lcc}
\hline Item & 1989 & 2007 \\
\hline $\begin{array}{l}\text { Total inheritance receipts to date } \\
\text { (trillions of dollars) }\end{array}$ & 1.5 & 2.4 \\
Median inheritance, conditional on receiving inheritance & 71,088 & 78,027 \\
Percent of households that have received inheritance to date & $23 \%$ & $17 \%$ \\
Percent of households without living parents & $25 \%$ & $21 \%$ \\
Average number of siblings for household head & 2.7 & 2.9 \\
\hline
\end{tabular}

Note: All amounts are in 2009 dollars.

Source: Authors' calculations based on the 1989 and 2007 SCF. 
Table 3. Distribution of Inheritances Received by Boomers, by Source

\begin{tabular}{lcc} 
Source & $\begin{array}{c}\text { Percent of total number } \\
\text { of inheritances }\end{array}$ & $\begin{array}{c}\text { Percent of total amount } \\
\text { of inheritances }\end{array}$ \\
\hline Parents & $63.2 \%$ & $74.1 \%$ \\
Grandparents & $20.4 \%$ & $16.5 \%$ \\
Aunt/uncle & $11.8 \%$ & $4.7 \%$ \\
Other & $4.6 \%$ & $4.8 \%$ \\
\hline Total & $100.0 \%$ & $100.0 \%$
\end{tabular}

Source: Authors' calculations based on the 2007 SCF.

Table 4. Estimated Distribution of Households by Anticipated Bequest, Respondents With More Than \$25,000 in Equity Assets

\begin{tabular}{|c|c|c|c|c|c|}
\hline \multirow{2}{*}{ Year } & \multirow{2}{*}{$\begin{array}{c}\text { Certain of } \\
\text { leaving nothing }\end{array}$} & \multicolumn{3}{|c|}{ Some probability of leaving } & \multirow{2}{*}{$\begin{array}{c}\text { Certain of leaving } \\
\$ 100,000+\end{array}$} \\
\hline & & $\$ 1-\$ 9,999$ & $\$ 10,000-\$ 99,999$ & $\$ 100,000+$ & \\
\hline 2000 & $2.1 \%$ & $2.3 \%$ & $19.0 \%$ & $54.1 \%$ & $22.5 \%$ \\
\hline 2002 & $2.4 \%$ & $2.6 \%$ & $20.4 \%$ & $54.0 \%$ & $20.5 \%$ \\
\hline 2004 & $2.8 \%$ & $3.0 \%$ & $21.8 \%$ & $53.6 \%$ & $18.7 \%$ \\
\hline 2006 & $2.4 \%$ & $2.6 \%$ & $20.2 \%$ & $54.0 \%$ & $20.9 \%$ \\
\hline
\end{tabular}

Source: Authors' calculations based on the 2000, 2002, 2004, and 2006 HRS. 
Table 5. Composition of Portfolios of Households Aged 65 and Over, 2007

\begin{tabular}{lc} 
Asset Class & Percent of Total \\
\hline Net Housing & $33.1 \%$ \\
Business Assets & $18.3 \%$ \\
Defined Contribution Assets & $9.4 \%$ \\
Net other nonfinacial assets & $7.9 \%$ \\
Net Financial Assets & $31.3 \%$ \\
Transaction Accounts & $4.4 \%$ \\
CDs & $2.3 \%$ \\
Mutual Funds & $6.0 \%$ \\
Stocks & $10.1 \%$ \\
Bonds & $2.4 \%$ \\
$\quad$ Other & $6.1 \%$ \\
\hline Total & $100 \%$
\end{tabular}

Source: Authors' calculations based on 2007 SCF. 
Figure 1. Distribution of Sum of Past and Prospective Inheritance Receipts for Boomers

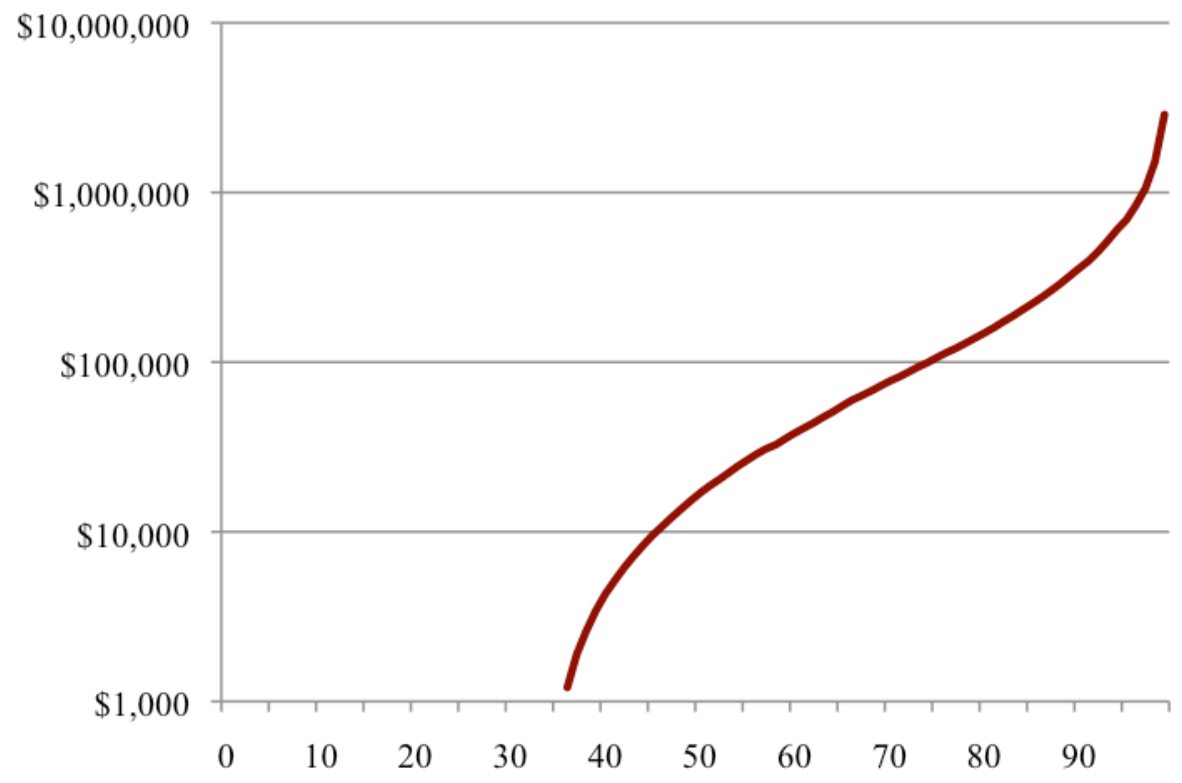

Source: Authors' calculations based on 2007 SCF and 2006 HRS.

Figure 2. Percent of Boomer Households Who Will Receive an Inheritance over Their Lifetime, by Income Decile

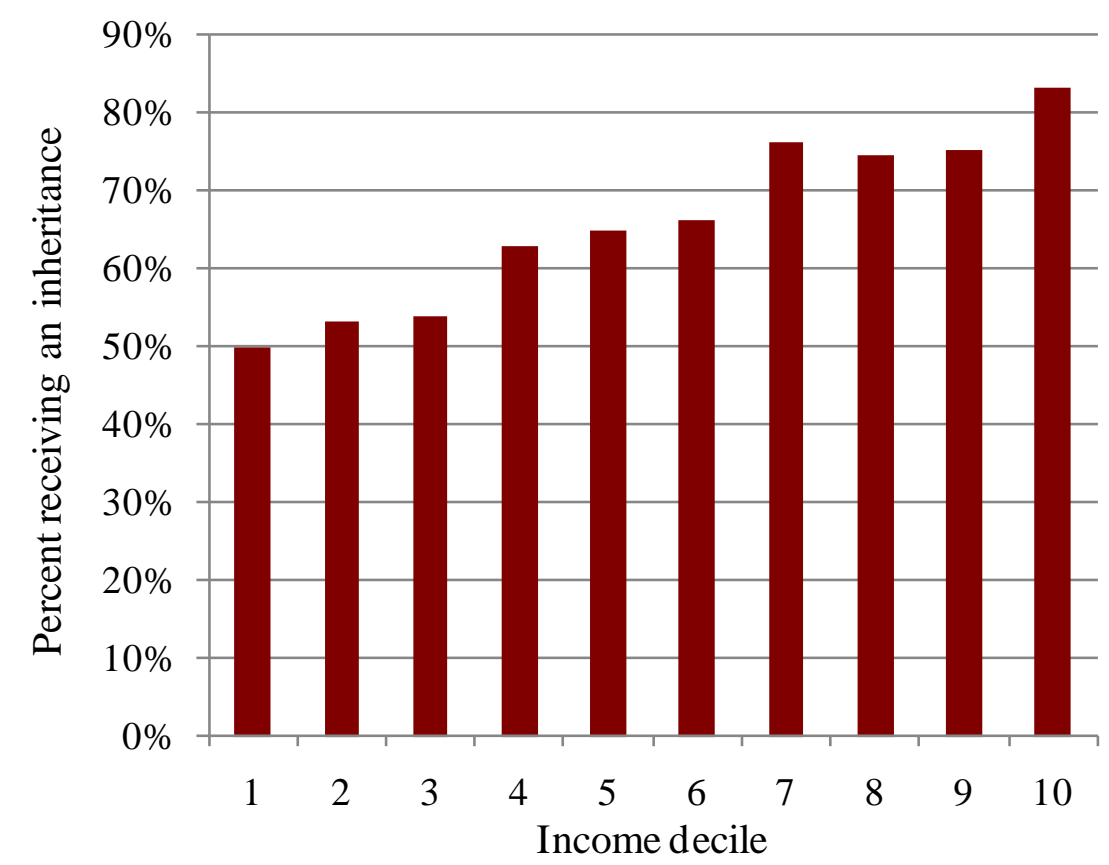

Source: Authors' calculations based on 2007 SCF and 2006 HRS. 
Figure 3. Mean Lifetime Receipt and Mean Lifetime Receipt as a Percent of Wealth for Boomers Receiving an Inheritance, by Wealth Decile

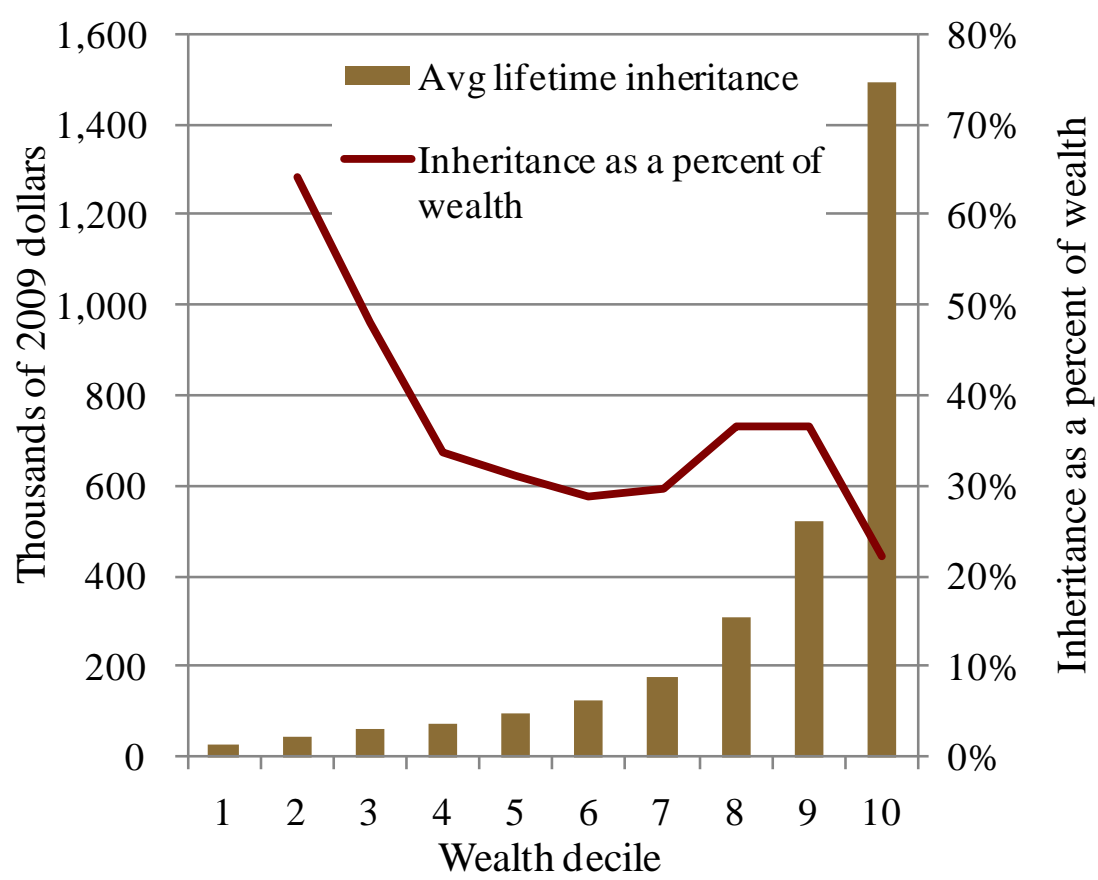

Source: Authors' calculations based on 2007 SCF and 2006 HRS.

Figure 4. Mean Inheritance Receipt for All Boomers by Wealth Decile

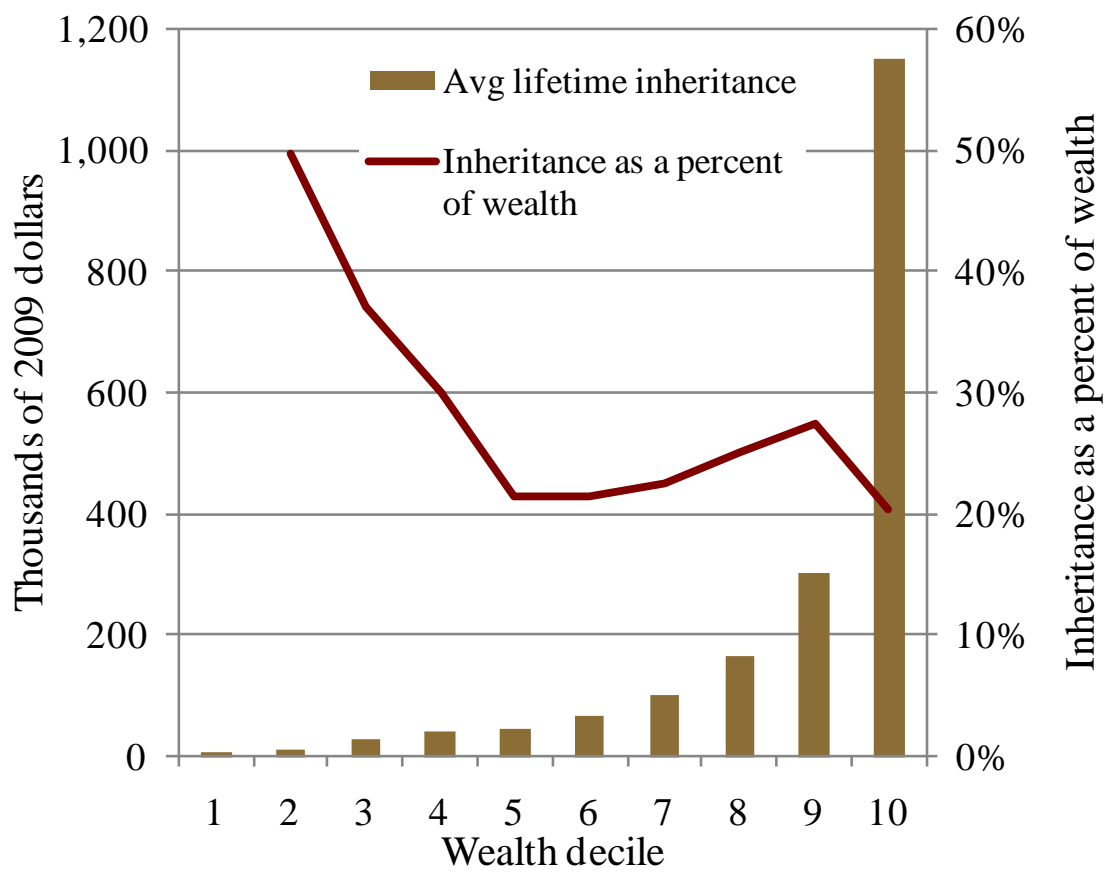

Source: Authors' calculations based on 2007 SCF and 2006 HRS. 
Figure 5. Percent of Boomers Receiving an Inheritance, by Age

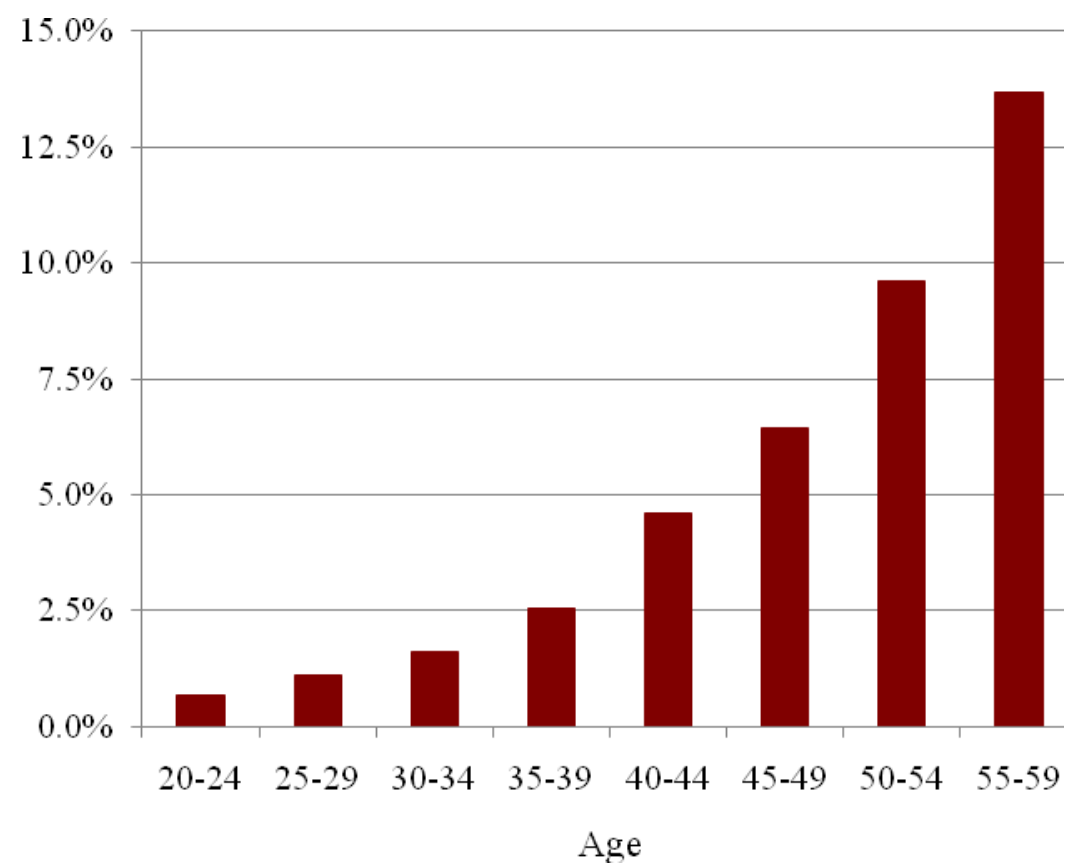

Source: Authors' calculations based on 2007 SCF. 


\section{RECENT WORKING PAPERS FROM THE}

\section{CENTER FOR RETIREMENT RESEARCH AT BOSTON COLLEGE}

Effect of Informal Care on Work, Wages, and Wealth

Courtney Harold Van Houtven, Norma B. Coe, and Meghan Skira, December 2010

Recessions, Wealth Destruction, and the Timing of Retirement Barry P. Bosworth and Gary Burtless, December 2010

Measuring the Spillover to Disability Insurance Due to the Rise in the Full Retirement Age

Norma B. Coe and Kelly Haverstick, December 2010

Is the Reduction in Older Workers' Job Tenure a Cause for Concern?

Steven A. Sass and Anthony Webb, December 2010

Accounting for Disability Insurance in the Dynamic Relationship Between Disability Onset and Earnings

Perry Singleton, November 2010

The Treatment of Married Women by the Social Security Retirement Program Andrew G. Biggs, Gayle L. Reznik, and Nada O. Eissa, November 2010

What is the Impact of Foreclosures on Retirement Security?

Irena Dushi, Leora Friedberg, and Anthony Webb, November 2010

Children and Household Utility: Evidence from Kids Flying the Coop

Norma B. Coe and Anthony Webb, November 2010

Overview of the CRR 2009 Retirement Survey

Alicia H. Munnell, Norma B. Coe, Kelly Haverstick, and Steven A. Sass, October 2010

State Wage-Payment Laws, the Pension Protection Act of 2006, and 401(k) Saving Behavior

Gary V. Englehardt, October 2010

Asset Cycles and the Retirement Decisions of Older Workers Jan Ondrich, October 2010

Price Deflators, the Trust Fund Forecast, and Social Security Solvency Barry Bosworth, October 2010

All working papers are available on the Center for Retirement Research website (http://crr.bc.edu) and can be requested by e-mail (crr@bc.edu) or phone (617-552-1762). 